\title{
Historical and philosophical foundations of A. Schopenhauer's philosophy
}

\author{
Amrekul Abuov - Aktoty Raimkulova - Raikhan Doszhan - Gulsaya \\ Kuttybekkyzy - Ulbossyn Aimbetova
}

DOI: $10.18355 /$ XL.2020.13.03.22

\begin{abstract}
This paper considers the evolution and origins of Schopenhauer's philosophy, analyzing its main topics, and concepts that appear in the manuscripts of the thinker, as well as the role that Schopenhauer's assimilation of the concepts and terminology of other thinkers played in the development of his ideas. As a result of our study, we made conclusions about the decisive influence on the design of the Schopenhauer system of philosophies of Kant, Fichte, Schelling, Schulze, as well as (to a much lesser extent) the works of some writers of German romanticism. One of the main results of the research was the opportunity to highlight several stages of the development of Schopenhauer's philosophy, during which it changed, having been influenced by earlier philosophical concepts. This study helps to Arthur Schopenhauer's philosophy within its historical context. Thus, it contributes to a more detailed development of relevant topics not only in relation to Schopenhauer proper but also in relation to the reception history of German classical philosophy and the very composition of its "pantheon." In addition, the work dispels many misconceptions regarding the genesis of Schopenhauer's philosophy and refutes the idea of its independence from the systems of his contemporaries. Finally, the results of this research help to genetically clarify many inconsistencies and contradictions in the concept of a mature Schopenhauer through the disclosure of the belonging of different elements of the corresponding concepts to the various stages of the formation of Schopenhauer's thought.
\end{abstract}

Key words: Schopenhauer, Kant, German classical philosophy

\section{Introduction}

The systems of Arthur Schopenhauer are a generalization of vast historical and philosophical experience that manifests itself in the form of a clash of views and a search for new solutions to philosophical issues, which elevates the problem of historical and philosophical continuity between thinkers. The ambiguous interpretation of Schopenhauer's key problems (such as problems of the law of sufficient foundation, free will, moral law) is a case in point. This also pertains to the question how the developed positions of one thinker is perceived, and how it passes into completely different consequences of another system. For example, in some studies, Schopenhauer is understood as a follower of Kant (Gardiner, 2003; Fleischer, 2003; Wirtz, 1910).

Moreover, we proceed from the fact that the theoretical principles of the whole system, which are consistent, are implemented precisely in the field of morality, which is an integral and dominant part of the whole system. An important and even essential moment in the modern world of information and technological progress is how individuals interact with each other, what moral guidelines they follow, etc..

Thus, the basis of interaction between subjects is the field of moral practice. In the research, we do not identify the concepts of "morality" and "moral." Our aim is to explore and substantiate the position, in which morality is the determining essence of the sphere of morality. Morality is the essence, the freedom of a rational being, which acts in accordance with generally binding laws. Morality, however, covers a wider range of human relations, namely: law, rituals, customs, and so on. 
Schopenhauer is often regarded as a seer, a pessimist, a staunch supporter of of the view that the human person is a purely egoistic being. After 1853, that is, after the publication of his work "Parerga und Paralipomena" ("Notes and Additions"), he had an increasing influence on the creative art and psychological science, first in Europe and then throughout the world. The tone of his thoughts was partially adopted by Wagner, but also Nietzsche and somewhat later by Freud. (Wagner, 1978), (Nietzsche, 1994), (Freud, 1933). He relied on this tonality not only on I. Kant, whom he thoroughly criticized, but also on M. Montaigne, F.M. Voltaire, and others. Unlike other German philosophical classics of the 19th - 20th centuries (Kant, Fichte, Schelling), Schopenhauer's works are "readable," that is, understandable by simple, literate persons, and not just philosopher specialists. Though his works are relatively easy to read, it is difficult for most readers to agree with his conclusions, despite of their convincing arguments.

Everyone knows the perennial controversy between idealism and materialism. Idealism asserts that only the ego exists, the various ideas, and seeks to explain matter from them. Materialism starts from the existence of matter and seeks to explain sensation from it. Schopenhauer tries to transcend these oppositions by saying that the existence of the whole world rests on subject and object, neither of which is anything at all on its own, but they exist only in their mutual relation: an object can exist only relatively to its subject and vice-versa. What makes this even more complicated is his assumption that the subject can be its own object. In that case we are again left with a subject and no object. He clarifies this as follows: the cognizing subject cannot be object, but the subject as willing can be object, so that the subject is split into a cognitive and a volitional one. The volitional is object of the cognitive. Questions as to a more detailed explanation he stops short by saying that this is the cosmic knot that cannot be disentangled. Schopenhauer then proceeds to what Kant calls forms of the intuition, time and space. (Boltzmann, 1974)

The relevance of the research topic is due to the fact that in the late XIX - early XXI century, the problem of man has become the central problem of philosophy. Having experienced a total crisis, mankind, at the turn of the millennium, is reconsidering the usual landmarks of its existence and development. In the ensuing debates that took place in the recent decades, habitual ideas about worldview coordinates are lost.

What is man today? What drives the inner struggles and motivates his soul? What connects him with the outside world? How to achieve the desired goals in this world? And is it possible to unconsciously trust all signals coming from outside, acting on the principle of "stimulus - reaction"? Man is still trying to explore himself, to understand his mission, to reveal his place in the universe. The matter is complicated by the fact that new models of this very universe pose new, unconventional questions and provoke new solutions.

The crucial crises that took place in public life and culture in the last century influenced people's mindsets, their attitude to the "philosophical faith", and the belief in the unlimited possibilities of the human mind (Jaspers, 1987). Reason, previously considered the universal tool of philosophy, is no longer a sufficient basis for the development of a holistic worldview. The agenda includes the study of the so-called "irrational" components of human life - intuition, will, instinct, faith, and properly interpreted feelings, emotions, etc.

The increased attention to all these phenomena by philosophers significantly limits the possibilities of rational knowledge. The worldview, as some recent thinkers state, is not always consciously formed by the individual himself, but is largely acquired "irrationally," as a result of direct influence on the personality of other people, as well as in the course of one's responses to ideological propaganda and advertising. In its formation and development, philosophy has reached a certain limit: acting, on the one hand, as a tool of cognition, being a completely sober, rational way of describing a

XLinguae, Volume 13 Issue 3, June 2020, ISSN 1337-8384, ISSN 2453-711X 
person and the world; on the other hand, it has come to the obvious conclusion that the world is largely illogical and irrational. But this means that the cognitive apparatus of a person is not the only factor in one's assessment of reality. Reason (if we use the concepts of (Kant, 1964), which Schopenhauer rejected), i.e. the main tools that philosophy has traditionally used, can no longer be considered authoritative evidence of truth, as it used to be during the time of Plato and Aristotle. Metaphysics is no longer a theory that studies only that which is subject to logic and speculation. Reason is no longer elevated to the rank of a deity, fastening and permeating the becoming material world, as it was with Stagirite.

To clarify Schopenhauer's criterion of the value of life and non-being, it is necessary to recall the philosopher's provisions on the will. When talking about the Copernican coup in worldview and science, it is useful to realize that there were other coups:

(1) Copernicus proved that the Earth is not the center of the cosmos.

(2) Kant proved that we could not know the world outside of us, outside of our thinking and self-awareness, outside of our cognitive activity, to know what it is in itself.

(3) Schopenhauer convincingly showed that our actions are never purely or even primarily rational; that reason serves our instincts, i.e., manifestations of the world will result in individual human identities. In this sense, Schopenhauer was far ahead of Sigmund Freud, his follower. Schopenhauer's will is absolute, the eternally active principle of the world, acting everywhere and always. In this, it differs from Kant's "thing in itself." (Sineokaya, 2010) But there is also a resemblance to the "thing in itself": "Strictly speaking, we know our own will always only as a phenomenon and never as it is by itself." (Die Welt als Wille und Vorstellung, 2010)

Schopenhauer interprets the entire world-process as a manifestation of creative elemental force - the will to live. The whole world process is an unconscious desire for life. This unconsciously positive desire to preserve is being in its highest form - in the form of accumulation of energy and information as opposed to entropy. The blind will to live is our deepest human being, it is the core of any life. Separate individuals are only a means to achieving its goal. The goal is their kind. (Die Welt als Wille und Vorstellung, 2010)

Cognition for the will is initially alien; as the metaphysical principle of the world, it simply wills, not cognizes. With the advent of the organic, living world, cognition also begins. It turns out that cognition does not begin with a person, which all living beings ("animalische Wesen") know and the difference between living beings in this regard in the proportions of the ratio between their will (instinct) and intelligence. The same applies to people as living beings: they also have very different proportions. Thus, he writes, "a phlegmatic person, that is, a weak, involuntary character, can be dispensed with a small intellect." (Die Welt als Wille und Vorstellung, 2010)

In cognition, the cognitive interest itself plays the decisive role, while impulses come from the will: material interest, status, position in society, recognition in it, selfaffirmation, etc. Moreover, is the truth is here? - the philosopher will ask rhetorically. The will is the foundation, the soil of all knowledge and all sciences, but it itself is incomprehensible, unknowable, inexplicable. A strong intellect seeks to hinder the actuality of its will, but this succeeds only to a small extent, if at all. The will determines the necessary actions of man, and therefore the will coincides with the need.

The will can deny itself by its own will, entering into the realm of the non-existence of the will, i.e., into nirvana. The formula "Convincing does not mean proven and true" in particular refers to the pessimism of Schopenhauer, which is reflected in his statements about the dominance of egotism in human behavior, and its interpretations of the value of life and death. In these views, he was followed by such celebrities as E. von Hartmann, (Nietzsche, 1994) and (Spengler, 1998). Schopenhauer's pessimism is briefly expressed in the following provisions: 
(1) There is no good God-creator who would save people from evil and would lead humanity and the whole world to a good future.

(2) Our world is a bestiary in which one looks at the other from the point of view of a victim.

(3) Fairytale notions of the future have always led to cruel disappointments.

(4) In the life of man and human society, there is no sense besides what they invent for themselves.

(5) There are no viable programs that could fundamentally remake human societies, neither socialist nor capitalist-democratic: human nature is fundamentally unchangeable.

(6) Optimists shouted at all times - we will continue, as we have done so far, and then the paradise, the golden age will come to Earth by itself (Kaiser-El-Safti, 1988).

The following Schopenhauerian principles are fundamental (Babtistsa, 2019)

1.Schopenhauer conceived several levels of the Will: (a) an unknowable primeval level, (b) the basic forces of nature (e.g., electricity, magnetism), (c) the Platonic Ideas, (d) all the inorganic and organic phenomena, and (e) the deliberate human actions as the pinnacle, constituting a tiny part of the whole Will.

2.Either individual phenomena or biological species are intended, never fully achieved copies of the ideal prototype.

3.With phenomena, selfishness appears because every phenomenon needs the matter, time, and space of other phenomena to exist. The alimentary chain may illustrate the concept of selfishness. At the ontological level of beings in general, the Will is thus insatiable. This is part of the metaphysical foundation of Schopenhauer's pessimism. (Baptista, 2019)

This philosopher is a pessimistic "seer" in assessing the correlation of pleasure and suffering, happiness and unhappiness in the fates of an individual and of all mankind. In the history of mankind, in relations between peoples and states, only during brief moments did the mind prevail over instincts and rage. And since history has not taught anyone anything (due to the incorrigibility of human nature), instinct and rage (instinct of grasping and rage of conquest) will prevail. Schopenhauer, as it were, foresaw that technological progress - the only true achievement of the mind of mankind - does not lead to the ideal of the Enlightenment (freedom, equality, and fraternity), but to an environmental disaster and self-destruction of mankind and, as a prelude, to the ever-greater enslavement of the majority of people by the minority.

Schopenhauer's general conclusion directly opposes the teachings of the optimist W. Leibniz about the existing world as the best possible. Schopenhauer claims that this world is the worst possible (Lutkehaus, 1980).

In the Foundations of Morality (1841), the author states that people are inseparably connected with selfishness. This philosophical position follows from the basic principle of Schopenhauer, according to which the whole world, and therefore all people, exist only in our view. On this view, the individual considers himself the center of the world and prefers his existence and good to everything else; everything that opposes his selfish aspirations causes his displeasure or even anger and hatred. The egoist would like everything that is possible to enjoy, to have everything. The egoist's slogan "Everything for me, remnants for others." Schopenhauer argues that in human behavior, as well as in animal behavior, orientation toward such actions that can have positive results for us is dominant. Later in psychology, this behavior was called "Lustprinzip" (to seek pleasure, to avoid suffering).

But long before Schopenhauer, this attitude was known and expressed by many intelligent people and reflected in popular wisdom. It was understood that the greatest force that separates people, which impedes the unity of society, are egoistic and asocial, people. It is much more tempting for them to pursue their own profit than to act morally, to consider and respect the interests of other people. The famous ancient

XLinguae, Volume 13 Issue 3, June 2020, ISSN 1337-8384, ISSN 2453-711X 
Greek speaker and politician Demosthenes claimed, "Everyone follows what benefits him." (Demosthenes) Schiller insisted, "Only profit rules the world." Similarly, T. Hobbes believed that both nature and society represent scenes of the merciless struggle of selfish individuals and that "Man is a wolf to man." The mutual extermination of people is partly hindered by the state, socialization, upbringing, religion, Hobbes noted, and not upbringing in itself. Schopenhauer agreed with this, despite his contempt for the untalented mob. And wisdom says: "Big fish eat small ones," "From someone else's misfortune our head doesn't hurt," "We measure our own misfortune with centners, others with grams," etc.

Egoism, which is especially pronounced in a situation of conflict of interests, cannot be equated with selfishness (Aristotle "virtuous must be selfish"), neither with individualism nor with hedonism, although all these teachings are closely related. In hedonism, all moral definitions are derived from the pleasure that everyone aspires to and the suffering that everyone avoids. On the one hand, hedonism affirms the intrinsic value of a person; on the other hand, hedonism is the basis for the apology of evil and immoralism when it insists that pleasure is the highest value. (Moore, 1984)

This brief introduction to the main topic gives, we believe, the possibility of a better understanding of Schopenhauer's attitude to issues of death and immortality. It shows that this philosopher, despite the "scandalous" nature of many of his propositions, is based on a great philosophical tradition. The following analysis, formulated above as hypothetical judgments, were substantiated and proved during the research, which provides the basis for the following conclusions.

In the middle of the XIXth century in Western European thought, a new kind of metaphysics was formed, which focused not on the values of cognitive consciousness and thinking, but on a specially comprehended will, as the ultimate philosophical category, understood as a world element or "force." The phenomenon of voluntarist metaphysics itself has appeared due to a whole complex of motivating reasons.

On the one hand, with the emergence of capitalist relations and against the backdrop of increasing scientific and technological progress, the negative aspects of the industrial revolution were noticed, and new crisis phenomena in the field of culture were discovered. In modern times, natural and historical sciences, in the methodology of which metaphysical and mechanistic approaches dominated, focused only on rationally comprehensible relations between things and people. In the XVIII-XIXth centuries, philosophy gradually concluded that many social processes and personality states could not be studied only with the help of the mind and cognitive "tools" of the human psyche. Some phenomena of life are accessible only to experience; they are not comprehended intellectually, but contemplatively and intuitively. The main means of actively comprehending such phenomena are philosophical and aesthetic intuition, persistent feeling, survival, etc.

On the other hand, these economic and socio-political processes took place against the backdrop of the crisis of the metaphysical method itself, the peak of which was German classical idealism. Kant's "critical philosophy," having proposed a satisfactory concept of organizing social life based on practical reason, in the realm of pure reason, faced a number of insoluble problems and, like (Hume, 1965), posited the unknowability of metaphysical data ("things in themselves"). In his system of thought, I.G. Fichte developed the strengths of the philosophy of (Kant, 1964) but bypassed the metaphysical questions he designated. (Schelling, 1993), following the romantics, went directly to the philosophy of contemplation and revelation.

In this case, only (Hegel, 1990) supported the idea of philosophy of revelation. However, his concept of the World Spirit is also largely borrowed from the theologians and has a pronounced strong-willed characteristic. If one looks closely, contains mystical features. Moreover, the Hegelian system, although it is rejects a metaphysical Aristotelian source, subsequently goes over to idealistic dialectics, essentially breaking with metaphysics. The philosophical system of Hegel turned out 
to be very popular in the scientific and political circles of Germany. This then became a reason for the emergence of an alternative "philosophy of will and representation" (A. Schopenhauer).

The Frankfurt thinker suggested a completely unexpected turn of metaphysical topics in those conditions, making the foundation of his teaching not a rational, but a spontaneous, strong-willed principle. It is not surprising that the philosophical public took so much time to perceive the concept of Schopenhauer in its entirety. Schopenhauer's metaphysical theory is distinguished by extreme pessimism (which he contrasted with the optimism of the "smooth" progress of the enlighteners), antirationalism, biologism in the interpretation of man and society, as well as pronounced voluntarism. The German thinker was one of the first to catch the negative consequences that the one-sided development of mankind could lead to and noticed the onset of the gap between "civilization" and "culture," which O. Spengler later writes about.

Schopenhauer's will is active, it expresses itself in various objectivities, but this selfexpression is devoid of any rational meaning. The will is inactive if we understand the activity as a rational sequence of actions to achieve certain goals. The new metaphysical principle of A. Schopenhauer is fundamentally untenable from a teleological point of view, which completely excludes the possibility of a rationalist dialectic, which was represented in the Hegelian idealist system and which was subsequently developed in detail in the historical materialist concept of K. Marx and F. Engels. Indeed, such a dialectic requires knowledge of the ultimate goals of development through which the subject must go. But A. Schopenhauer ignores any goals in his system composed of ideas and a volitional world. Any goal-setting is relative and does not bring anything to the subjects but satiety and suffering.

As a result, the World Will, having gone through a series of natural objectivations, returns to the original beginning in man through art, in particular, in music, which reflects the essence of the struggles of the will, which is an eternal formation. The limitless imagery in music is unique; it allows you to organically weave your own fantasies and experiences into the author's plan. On an irrational, intuitive level, music penetrates the soul, touching the mysterious and inexplicable inner world of the individual.

Music, as the highest manifestation of spirituality, mystically comprehends this truth. It is characteristic that in this place, the philosophy of art of A. Schopenhauer intersects with the philosophy of art of G. Hegel, although unlike his senior colleague at the University of Berlin, the Frankfurt thinker does not consider poetry the highest form of art. Words are rude; they cannot even roughly express what life is. Only the musical formation, birth, and dying of absolute sound can transmit the pulse and heartbeat of suffering living creatures in the whirlpool of the World Will.

The idea of the musical and expressive formation of A. Schopenhauer is a kind of bridge to both the individualistic philosophy of F. Nietzsche and the musical and dramatic work of R. Wagner. F. Nietzsche accepts and develops the biologizing and voluntarist ideas of A. Schopenhauer. Society is the sum of individuals that differ from animals only in their ability to recognize and evaluate their actions.

Overcoming the pessimism of A. Schopenhauer, F. Nietzsche, on the contrary, is trying to create a philosophy of active action, one of the central categories, which is "the will to power," or rather - the "will to power." In an ontological interpretation, the whole cosmos appears as a struggle of "quanta of power." The psychological interpretation brings the various qualitative states of the psyche (instincts, emotions, intelligence, etc.) into a single moving principle.

But volitional power and talent for super-willpower are different for different people. In a strong person, creation and creator are organically connected. It has, on the one hand, matter, madness, chaos, on the other - creativity, creation, firmness. The first 
qualities are inherent in ordinary people who create material wealth and have a weak "will to power." The second - to noble people, "aristocrats of the spirit" who are called to create "higher" values and have an increased content of "will to power." Thus, history is a struggle of two types of wills, says F. Nietzsche.

In his opinion, cognition is just a means of expressing fiction, for there is no constancy in the world. It allows a person to survive and fulfill his "will to power." Cognition is an instrument of the "will to power"; it is not aimed at theoretical comprehension of the world, but at the practical mastery of it. The pursuit of knowledge is based on instincts and subjective desires. The logical laws created by rational scientific knowledge are something universal, and therefore "mediocre." Logic only generalizes knowledge.

Metaphysics and the world in the interpretation of F. Nietzsche resemble the metaphysical theory of T. Hobbes, set forth in Leviathan. But if the English philosopher-empiricist has a reasonable beginning, the ability of people to come to an agreement, takes precedence over people's instincts, and this is understood as a positive beginning, which creates the state as a complexly organized "artificial body," then this approach is unacceptable for F. Nietzsche. The way out of the chaos of the natural ("Dionysian") state is only in personal work on oneself, a firm and consistent change in one's nature. Every social organization for managing the vital forces of people is sharply criticized by F. Nietzsche. In fact, he did not answer the question of how to organize social life so that, on the one hand, the self and "will for power" of strong individuals do not suffer, and on the other hand, the strength and desire of individuals with a lack of "will for power" "were encouraged to overcome themselves. For the first time in Western philosophy, the irrationality, voluntarist, biologizing concept of F. Nietzsche creates the "tradition of negating traditions." The reason for the appearance of this point of view is the rejection of existing cultural and social values.

Developing the idea of world musicality advanced by A. Schopenhauer, R. Wagner created his own musical theater. The man in his works is shown in a clash with mystical forces derived from natural will and is hostage to their games and intrigues. The personal will of an individual who finds himself in similar circumstances, his heroism, and his readiness for a tragic loss are shown as interpretations of the voluntarist metaphysics that R. Wagner proposed in his philosophical and aesthetic concept.

In general, differences in philosophical doctrines of the thinker stem from various metaphysical interpretations of the will and attitude of a person to it and ultimately come down to pessimism or optimism. The very existence of such irrationality tendencies in a broad sense can be traced throughout the history of philosophy. In a narrower sense, the irrational concepts that emerged in the 19th century, combined with a negative attitude to the rationalist belief in the limitless possibilities of the human mind, sought either to completely refute rationalism or to limit it. But at the same time, they proposed new interesting concepts for understanding rationality itself.

\section{Bibliographic references}

BOLTZMANN L. 1974. On a Thesis of Schopenhauer's. In: McGuinness B. (eds) Theoretical Physics and Philosophical Problems. Vienna Circle Collection, vol 5. Springer, Dordrecht, Print ISBN978-90-277-0250-0, DOI https://doi.org/10.1007/978-94-010-2091-6_14

BAPTISTA, T. - ALDANA, E. - ABRAMSON, CH.I. 2019. Arthur Schopenhauer and the Current Conception of the Origin of Species: What Did the Philosopher Anticipate?,

SAGE Open, vol. 9, n. 1, doi.org/10.1177/2158244019837467

WAGNER, R. 1978. The public and popularity Elect. work. In: Art, pp. 625-651 ISBN-10: 0486235661 
NIETZSCHE, F. 2003. Morning Dawn. Thoughts on moral prejudices / F. Nietzsche // Nietzsche F. Morning Dawn. Preliminary work and additions to the "Morning Dawn." Revaluation of all valuable. Science publishing house. Minsk, pp. 3-224. ISBN-10: 9351283755

SCHOPENHAUER A. 1992. Freedom of will and morality. (J. Paine translation), New-York, Berg., pp. 19-249. ISBN 978-1-84465-008-8

SCHOPENHAUER, A. 2001.World as a Will and a Representation. T. 2 / edition: in 6 volumes / A. Schopenhauer. -Moscow publishing house., vol. 2.- p. 3-544. ISBN13: 978-0521871846

HEGEL, G.V.F. 1993.Lectures on the philosophy of history. - SPb., 479 p. ISBN-13: 978-9076660141

KANT, I. 1964. Criticism of Pure Reason Works: 6 vols. - Moscow publishing house., -T. 3.756 p. ISBN-13: 978-0312450106

FISHER, K. - SCHOPENHAUER, A. 1999. St. Petersburg, 608 p. ISBN-13: 9781113737670

HEIDEGGER, M. 1993. European nihilism. Five main rubrics in Nietzsche's thoughts.Time and Being: Articles and Speeches. Moscow publishing house., p. 63176. ISBN (13): 978-1-5275-0880-4

HEIDEGGER, M. 1997. Introduction to Metaphysics SPb., 301 p. ISBN 0-30008327-0

SCHELLING, F.V.J. 1987. The system of transcendental idealism. Works: in 2 vols. Moscow publishing house., n. 1. pp. 227-489. ISBN-10: 0813914582

SCHELLING, F.V.J. 1996. Philosophy of Art. -SPb., -496 p. ISBN-10: 0813914582

SPENGLER, O. 1993. Sunset History. Essays on the morphology of world history: in 2 volumes, Moscow publishing house., vol. 1.663 p. ISBN-10: 1912759012

HUME, D. A. 1965. Treatise on human nature, or an attempt to apply the experimentally based method of reasoning to moral subjects Works: 2 vol. Moscow publishing house., - T. 1. pp. 77- 788. ISBN 978-1-349-71193-2

JUNGER, F.G. NIETZSCHE. 2001. -M., 256 p. ISBN-13: 978-8425437151

JASPERS, K. 1991.Philosophical Faith. The meaning and purpose of history. Moscow publishing house., p. 419-508. ISBN-13: 978-0300097351

DAHLHAUS, C. 1971. Wagners Konzeption des musikalischen Dramas. Regensburg, - 124 p. ISBN 13: 9783764920616

FUNKE, G. 1979.Von der Aktualität Kants. Bonn, - 273 p. ISBN 978-3-88309-393-2

MAHNKOPF C.-ST. 1999. Wagners Philosophie der Eros. Musik-Astetik / C.-St. Mahnkopf. Stuttgart,.- 178 p. ISBN 3-923997-8

MAGEE, B. 1983. The philosophie of Schopenhauer, Oxford, 400 p. ISBN-10: 0198237227

MALTER, A. 1991. Arthur Schopenhauer: Transzendentalphilosophie und Metaphysik des Willtns. Stuttgart, 476 p. ISBN-10: 377280991X

PAULEIKHOFF, B. 1997.Richard Wagner als Philosoph. Stuttgart, -391 p. ISBN13: 9783876460857

PHILONENKO, P. 1990. A. Le transcendental et la pensée modem: Etudes d'histoire de la philosophie, 308 p. ISBN-10: 2130425917

GARDINER, P. 2003.Arthur Schopenhauer. Philosopher of German Hellenism. In.: CJSC Centropoligraf, ISBN-13: 978-1855065253

FLEISCHER, M. 2003.Schopenhauer als Kritiker der Kantischen Ethik. Würzburg: Konigshausen \& Neumann GmbH. ISBN-10: 3826024702

WIRTZ, H. 1910.Schopenhauers Ideenlehre im Vergleich zu der Piatos und Kants. Aachen: La Ruell'esche Accidenzdrukerei ISBN: 9780274726271

LUDENDORFF, M. 1976.Ein Wort der Kritik an Kant und Schopenhauer. Pähl: Franz von Bebenburg KG. ISBN: 9783882022742 
FREUD, Z. 1933. New Introductory Lectures on Psycho-analysis, Lecture A Philosophy of Life, publ. Hogarth Press ISBN-10: 9780393007435

SUCKAU, O. 1912. Schopenhauers falsche Auslegung der Kantischen Erkenntnistheorie. Weimar: Druck von R. Wagner Sohn, adhere. ISBN-10: 1314423150

SINEOKAYA, YU.V. 2010. Schopenhauer A. In: Philosophical Encyclopedia in 4 volumes, Moscow publishing house, T. 4, p. 391, ISBN 978-5-8291-2473-1

SCHOPENHAUER, A. 2010. Die Welt als Wille und Vorstellung. Köln Anaconda Verlag GmbH. Ergänzungen zum vierten Buch. 41. Über den Tod und sein Verhältnis zur Unsterblichkeit unseres Wesens an sich, p. 875, note, 27 PhfA, p. 447, ISBN-13: 978-3423306713

KAISER-EL-SAFTI, M. 1988. Der Nachdenker. Die Entstehung Metapsychologie Freuds und ihre Abhängigkeit von Sachopenhauer und Nietzsche. Bonn, Bouvier Verlag. ISBN 10: 3416019814

LUTKEHAUS, L. 1980. Metaphysischer Pessimismus und soziale Frage. Bonn, Bouvier Verlag. ISBN, 3416015614

DEMOSTHENES. Three appearances against the Macedonian king Philip II., Known as the "Philippe". The third performance. ISBN 9780199738151

MOORE, J.E. 1984. Principles of Ethics. Moscow publishing house, pp. 127179. ISBN-13: 978-0486437521

B. SPINOZA, 1957. Selected Works, vol. 1. Moscow publishing house, p. 576. ISBN. 9781310367274

SCHRODINGER, E. 1947. What is life in terms of physics? Moscow publishing house. ISSN: 0073-2753

Words: 5146

Characters: 33525 (18,63 standard pages)

Amrekul Abuov

Akhmet Yassawi International Kazakh-Turkish University

Bekzat Sattarkhanov Avenue, 29

city Turkestan,

Kazakhstan

nurzhanzhan@mail.ru

Aktoty Raimkulova

Kazakh National university of Art

Prospect Tauelsizdik, 50

city Nur-Sultan

Kazakhstan

bislauka@mail.ru

Raikhan Doszhan

Gulsaya Kuttybekkyzy

Ulbossyn Aimbetova

Kazakh National academy of choreography

Uly Dala Avenue 9

city Nur-Sultan

Kazakhstan

nurbeklunara@mail.ru 